\title{
National ethics guidance in Sub-Saharan Africa on the collection and use of human biological specimens: a systematic review
}

\author{
Francis Barchi ${ }^{*}$ (I) and Madison T. Little ${ }^{2}$
}

\begin{abstract}
Background: Ethical and regulatory guidance on the collection and use of human biospecimens (HBS) for research forms an essential component of national health systems in Sub-Saharan Africa (SSA), where rapid advances in genetic- and genomic-based technologies are fueling clinical trials involving HBS and the establishment of large-scale biobanks.

Methods: An extensive multi-level search for publicly available ethics regulatory guidance was conducted for each SSA country. A second review documented active trials listed in the WHO International Clinical Trials Registry Platform as of January 2015 in which HBS collection was specified in the protocol. Findings were combined to determine the extent to which countries that are study sites for HBS-related research are supported by regulatory guidance language on the collection, use, ownership and storage of biospecimens.

Results: Of the 49 SSA countries, 29 had some form of national ethics guidance, yet only 17 provided language relating to HBS-related research, with specific guidance on consent (14), ownership (6), reuse (10), storage (9), and export/import/ transfer (13). Ten countries accounted for $84 \%$ of the active clinical trials involving the collection of HBS in SSA. All except one of these countries were found to have some national guidance in the form of regulations, codes of ethics, and/or standard operating procedures; however, only seven of the ten offered any language specific to HBS.

Conclusions: Despite the fact that the bulk of registered clinical trials in SSA involving HBS, as well as existing and proposed sites for biorepositories under the H3Africa Initiative, are currently situated in countries with the most complete ethics and regulatory guidance, variability in the regulations themselves may create challenges for planned and future pan-African collaborations and may require legislative action at the national level to revise. Countries in SSA that still lack regulatory guidance on HBS will require extensive health system strengthening in ethics governance before they can be full participants in the modern research enterprise.
\end{abstract}

Keywords: Sub-Saharan Africa, Biospecimens, Biobanks, Ethics guidance, Regulatory systems, Ethics committees, Health systems, Materials transfer agreements

\section{Background}

Exponential growth in the fields of pharmacogenetics and genomics research over the past decade is fueling worldwide interest in the establishment of biorepositories of human biological specimens. Biorepositories already exist in three SSA countries-The Gambia, South Africa, Zimbabwe [1-3]. Major expansion in this domain is occurring in Sub-Saharan Africa, largely

\footnotetext{
* Correspondence: francis.barchi@rutgers.edu

${ }^{1}$ Edward J. Bloustein School of Planning and Public Policy, Rutgers

University-New Brunswick, 33 Livingston Street, New Brunswick, NJ 08901, USA

Full list of author information is available at the end of the article
}

driven by the Human Heredity and Health in Africa Initiative (H3Africa), a joint effort of the National Institutes of Health (NIH), the Wellcome Trust, and the African Society for Human Genetics [4]. The 'hub and spoke' model adopted by this initiative calls for the development of four pilot regional biobanks - two in South Africa and one each in Nigeria and Uganda - which will serve as multi-country repositories of specimens collected under sponsored research activities taking place throughout the region [5]. The H3Africa Initiative reflects significant efforts by the international community of researchers, 
funding agencies, and African academic institutions to build a foundation for sophisticated, state-of-the-art genomic research on burdensome diseases in Africa; the ultimate goal of the initiative is to improve the health of the African peoples.

From its inception, the initiative has sought broad consensus on topics relating to ethics and governance A Joint NIH and Wellcome Trust Policy document sets forth high-level principles on ethics, governance, and resource sharing with which research networks and programs funded by the initiative are expected to comply [6]. A standing working group on ethics and regulatory issues comprising ethicists and other members of the scientific community meets periodically to discuss and develop recommendations on a wide range of topics including community engagement strategies, cultural issues, informed consent, participant safety, return of results, intellectual property, material transfer agreements, and other regulatory issues. While such guidance has the potential to serve as a model framework for all countries in Africa to consider as they develop their own national guidelines, the current focus of the initiative is on those entities that it supports. Applied more broadly, the pan-continental approach espoused by H3Africa and similar initiatives may require a level of ethical guidance at the country level explicitly addressing the collection and use of HBS which is currently not to be found in most national ethics regulatory guidance. In many African countries, such systems are in their infancy; policies that address emerging technologies such as whole genome sequencing and association studies are absent $[7,8]$.

The International Declaration on Human Genetic Data, promulgated by UNESCO in 2003, recognized the importance of national policies to guide the collection, processing, use, and storage of human genetic data, as well as the review by local and institutional ethics committees of protocols involving such data [9]. In Africa specifically, a growing body of literature has focused on the need to have ethical and legal governance structures in place to oversee research involving HBS and the operation of biobanks $[10,11]$.

If the H3Africa vision of a pan-continental genomic enterprise is to be fully realized, ethics guidelines at the national level must align in ways that support interoperability among African countries. In cases where no guidelines presently exist, investment in institutional capacity-building by such entities as H3Africa and others may be needed to support their development. In cases where national guidelines do exist, some may require the addition of new language specific to research involving HBS; such revisions may require legislative approval. There may be instances where national values simply will not support the transnational transfer of genetic information, broad data sharing within research communities (however relevant to their populations), or the delegation of decision-making on future use to an outside authority. The lack of interoperability among African nations in their ethics guidance as well as differences in interpretation of meaning in instances where international recommendations have been adopted has the potential to slow, even derail, the realization of benefit from new advances and approaches in biomedical research [10,12].

Although a number of scholars have examined the ethical, legal, and social issues associated with the collection and use of biospecimens in research, there has been far less focus on the existence and nature of regulatory guidance on HBS at the national level in Sub-Saharan Africa $[8,11-17]$. Of particular importance is the identification of national 'gaps' in ethics guidance, as well as inconsistencies and national differences among those countries where guidance does exist.

\section{Methods}

This study involved two systematic reviews designed to determine the availability of publicly accessible regulatory HBS guidance at the national level in SSA countries and to assess the extent to which it addressed ethical and regulatory issues relating to consent, ownership, reuse, storage, and export/import/transfer. Two reviews were conducted as part of this project. The first involved a multi-level search to identify publicly available national research ethics guidance on the collection and use of HBS in countries in Sub-Saharan Africa. This process, detailed in Table 1, involved keyword searches, on-line reviews of international ethics databases and regional and national government websites, and, in those instances where online efforts yielded no results, direct contact via email with national ethics committees and scans of ethics review statements included in previously published journal. National ethics guidance was operationalized to include enabling legislation for the creation and constitutions of national research institutes and national research ethics committees, codes of ethics, national ethics guidelines, and standard operating procedures. We excluded those documents that only provided instructions to researchers on how to submit their protocols, instruction on writing consent documents, and organizational information from research ethics committees that were not identified as being national in jurisdiction. Materials Transfer Agreements (MTA) and Specimen Transfer Agreements (STA) for specific countries were included in our search but were only used as a source of guidance if we could find a specific reference to "human" biological specimens. We limited our results to those national documents that we could access publicly on-line or secure through contact with the national regulatory body, reasoning that guidelines that were inaccessible via such mechanisms would be of limited utility to the research community. 
Table 1 Search strategy and selection criteria

\begin{tabular}{|c|c|}
\hline Level & Components of search \\
\hline evel 1 & $\begin{array}{l}\text { Search Engines: Google, Google Scholar, PubMed, National Library of Medicine } \\
\text { Keywords: Name of country + each of the following terms: } \\
\text { human biological specimens, biobanks, ethics regulations, research ethics, ethics regulations, ethics committee, bioethics, consent, human } \\
\text { subjects research, drug regulation, research regulations, institutional review boards, ethics review committees, materials transfer } \\
\text { agreement }\end{array}$ \\
\hline vel 2 & $\begin{array}{l}\text { On-line directories: } \\
\text { Canadian Coalition for Global Health Research (CCGHR). www.ccghr.ca } \\
\text { Harvard Research Ethics Guidelines International Online Navigation Map (REGION). https://www.hsph.harvard.edu/region-map/ } \\
\text { Health Research Web (HRWeb). https://healthresearchweb.org/en/africa } \\
\text { Office for Human Research Protections (OHRP). International Compilation of Human Research Protections. http://www.hhs.gov/ohrp/sites/ } \\
\text { default/files/internationalcomp2016\%20.pdf } \\
\text { Training and Resources in Research Ethics Evaluation (TRREE). http://elearning.trree.org/ } \\
\text { UNESCO - Assisting Bioethics Committees (ABC) http://www.unesco.org/new/en/social-and-human-sciences/themes/bioethics/assisting- } \\
\text { bioethics-committees/ } \\
\text { UNESCO Global Ethics Observatory. http://www.unesco.org/new/en/social-and-human-sciences/themes/global-ethics-observatory/ } \\
\text { WHO African Health Observatory (Health Systems) http://www.aho.afro.who.int/en/atlas/health-system } \\
\text { WHO MINDbank. https://www.mindbank.info/ }\end{array}$ \\
\hline Level 3 & $\begin{array}{l}\text { Web sites of regional ethics organizations: } \\
\text { Pan African Bioethics Initiative (PANBIN). http://www.who.int/sidcer/fora/pabin/en/ }\end{array}$ \\
\hline Level 4 & Direct contact via email with National Ethics Committees in Sub-Saharan African countries \\
\hline Level 5 & $\begin{array}{l}\text { 1. Scan of journal articles on biomedical research in specific SSA countries to identify: } \\
\text { a. Ethics Review Statement: Name of African REC, if any, that conducted an ethics review of research protocol } \\
\text { b. Names of US researchers who have worked in that particular African country } \\
\text { 2. Check web for identified IRB/ERC/approval granting regulatory body } \\
\text { 3. Contact individual researchers by email to request information about IRB reviewing procedures and familiarity with regulations (if any) } \\
\text { governing collection and use of HBS. }\end{array}$ \\
\hline
\end{tabular}

A second review was conducted using the WHO International Clinical Trials Registry Platform (ICTRP) to identify registered clinical trials taking place in Sub-Saharan Africa as of January 1, 2015, and, of these, the number of clinical trials in each country that called for the collection of HBS as part of the study protocol [18]. The ICTRP is a web-based, publicly accessible compilation of studies that have been registered in any of the following databases: Australian New Zealand Clinical Trials Registry (ANZCTR); Chinese Clinical Trial Registry (ChiCTR); ClinicalTrials.gov; EU Clinical Trials Register (EU-CTR); ISRCTN; The Netherlands National Trial Register (NTR); Brazilian Clinical Trials Registry (ReBec); Clinical Trials Registry India (CTRI); Clinical Research Information Service Republic of Korea (CRiS); Cuban Public Registry of Clinical Trials (RPCEC); German Clinical Trials Register (DRKS); Iranian Registry of Clinical Trials (IRCT); Japan Primary Registries Network (JPRN); Pan African Clinical Trial Registry (PACTR); Sri Lanka Clinical Trials Registry (SLCTR); and Thai Clinical Trials Register (TCTR). Included in the count of active clinical trials were those trials listed in the database as active/not recruiting; recruiting; not yet recruiting; authorized-recruitment/may be ongoing or finished; and pending. Studies were excluded if identified as not recruiting; complete; terminated; closed/follow-up continuing; closed to recruitment/ follow-up complete; temporary halt or suspension; other; not applicable; or withdrawn. The process used to identify active trials calling for HBS collection is illustrated in Fig. 1.

\section{Results}

Table 2 summarizes the availability of national ethics guidance irrespective of content as well as guidance language specific to HBS in each of the 49 countries

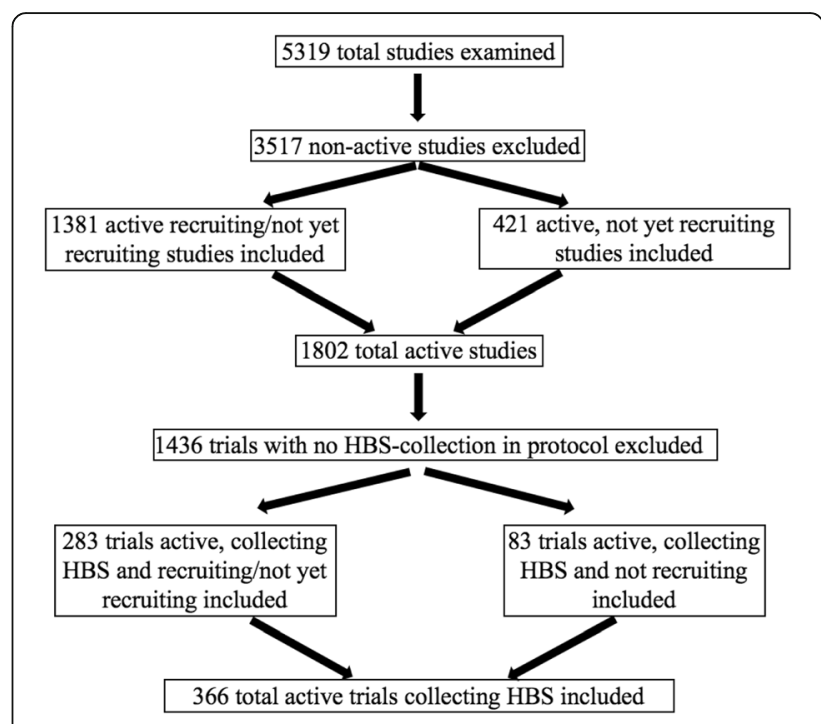

Fig. 1 Research process for identifying active clinical trials in SSA involving HBS collection (Source: WHO-ICTRP as of January 1, 2015) 
Table 2 SSA countries with HBS-related information in legislative/regulatory/guidance ethics documents

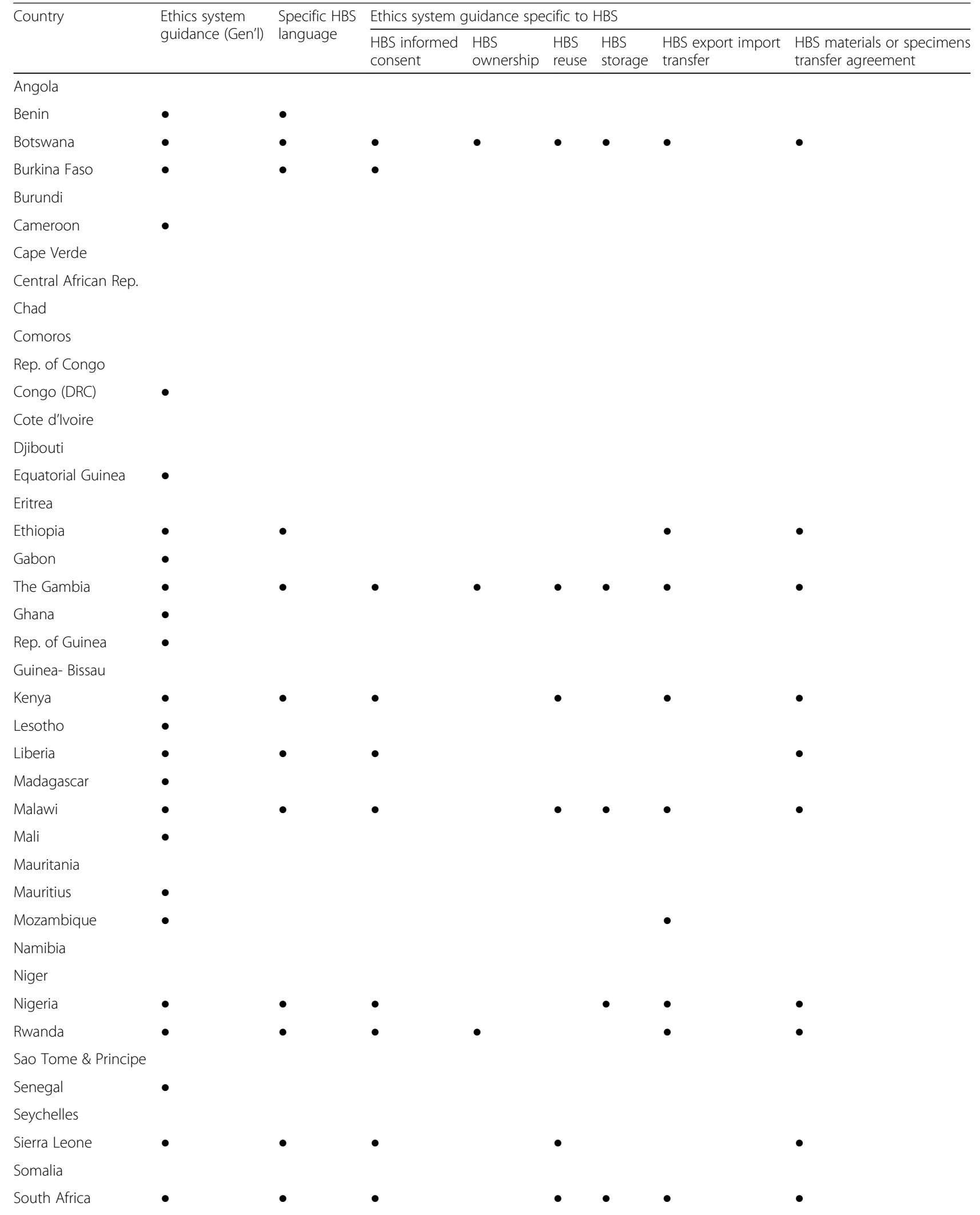


Table 2 SSA countries with HBS-related information in legislative/regulatory/guidance ethics documents (Continued)

\begin{tabular}{|c|c|c|c|c|c|c|c|c|}
\hline South Sudan & & & & & & & & \\
\hline Sudan & - & - & - & & - & & & \\
\hline Swaziland & & & & & & & & \\
\hline Tanzania & - & - & - & - & - & - & & - \\
\hline Togo & & & & & & & & \\
\hline Uganda & $\bullet$ & $\bullet$ & $\bullet$ & $\bullet$ & $\bullet$ & $\bullet$ & $\bullet$ & $\bullet$ \\
\hline Zambia & - & - & - & - & - & - & - & - \\
\hline Zimbabwe & $\bullet$ & $\bullet$ & & & & $\bullet$ & $\bullet$ & $\bullet$ \\
\hline TOTAL & 29 & 17 & 14 & 6 & 10 & 9 & 12 & 13 \\
\hline
\end{tabular}

included in the WHO region constituting Sub-Saharan Africa. Detailed information on the specific content of any HBS-related language is provided in Table 3. Twenty-nine (60\%) of the countries in the region had some national ethics guidance, either in the form of laws, regulations, codes, guidelines, or standard operating procedures. Of these 29 countries, however, twelve did not have regulations that addressed specific guiding principles or rules for ethics research or review. Six (Congo DRC, Equatorial Guinea, Republic of Guinea, Lesotho, Madagascar, and Mali) had regulatory language that was limited to establishing or defining the functions and constitution of research ethics committees. One (Mauritius) had drafted a code of research ethics that was distributed for public comment in 2003, but no documentation could be found that it had been operationalized. Three countries (Cameroon, Mozambique, Rwanda) offered limited language specific to guiding principles or ethical conduct of research, but link their review processes to the ethical guidance contained in the Declaration of Helsinki, CIOMS, or the ICH-GCP [19-21]. No national guidelines for general ethical conduct of research could be found for The Gambia, but the Medical Research Council - The Gambia had published very detailed guidelines for the collection and use of biospecimens stored in the National DNA Bank of The Gambia which we have included in our analysis [22]. In addition, two countries (Chadand Gabon) had been working with UNESCO on the establishment of national ethics committees but no regulatory documentation could be found [23, 24].

More than one half (59\%) of the countries whose guidelines articulated ethical principles or guidelines for ethical review include some language to guide the collection and use of HBS for biomedical research. Fourteen of these offered some language with respect to informed consent; 10 addressed the subject of reuse; and 12 contained specific language relating to export/ import/transfer. Only six countries offered language with respect to HBS ownership and nine contained language regarding storage. Thirteen required that a Materials or Specimens Transfer Agreement be executed. Table 4 reports the findings with respect to registered, active clinical trials in Sub-Saharan Africa that called for the collection of HBS. Of the 5319 studies identified in the WHO International Clinical Trials Registry Platform, 1802 of were currently active as of January 1, 2015. Three hundred sixty-six (366) of these involved the collection of a biosample from research subjects. The distribution of these trials across the region are illustrated in Fig. 2.

Table 5 reports on the ethics system guidance on HBS found in the countries where the largest number of studies involving HBS are currently taking place in SubSaharan Africa. These 10 countries account for nearly $82 \%$ of the active clinical trials involving the collection of HBS in the region that were registered in the WHO International Clinical Trials Registry Platform as of January 1, 2015. They included the five countries that either have existing biorepositories (The Gambia, South Africa and Zimbabwe) or planned to establish regional biorepositories in the near future as part of the H3Africa Initiative (Nigeria, South Africa and Uganda). All ten of these countries had some form of ethics system guidance in the form of regulations, codes of ethics, standard operating procedures, or guidelines, and, with the exception of Mali, provided some regulatory language at the national level as to the collection and use of HBS. Notably only four of these countries (The Gambia, Kenya, Uganda, and Zambia) included language in their national ethics documents on the ownership of HBS. Mali, where at the time of our study there were currently 10 registered active trials requiring a biosample, had no guidance language on HBS in its national ethics documents. Although most of the countries in which large biorepositories existed or are planned as part of H3-Africa contain fairly detailed HBS language in their guidelines, only two (The 
Table 3 National regulatory guidance language on collection and use of HBS by country*

Legislation, regulations, Specific HBS language HBS consent HBS ownership

HBS secondary use

HBS storage

HBS Import/export

and/or guidance re.

\section{Angola}

None found

None found

None found

None found

None found

None found

None found

Benin

Loi 2005-31 Portant prevention, prise en

Loi 2005-31 portant

No language

No language

No language

No language

No language

prevention, prise en

$\mathrm{VIH} / \mathrm{SIDA}$ en Republique

$\mathrm{VIH} / \mathrm{SIDA}$ (2006) [28]

Loi No. 2010-40 portant

code d'éthique et de

déontologie pour la

du Benin (2005)

Loi No. 2010-40 Portant

code d'éthique et de

$\begin{array}{ll}\text { recherche en santé en } & \text { déontologie pour la } \\ \text { République du Bénin (8 } & \text { recherche en santé en }\end{array}$

December 2010) [29]. République du Bénin (8

December 2010).

Botswana

Botswana Statute Law: Ministry of Health

Anthropological Research Standard Operating

Act 1967 [30] $\quad$ Procedures, Article 7.2

Drugs and Related Procedures on Human

Substance Act, 1992 [31] Genetic Research, pages

Botswana Drugs Advisory 103-108.

Board: Guidelines on drug Articles 8.1-8.5, Human

registration applications in Biological Materials, pages

Botswana [4th edition] 111-114

2014.[32]

Botswana Ministry of

Health, Standard

Operating Procedures for

Review of Biomedical and

Bio-behavioral Research in

Botswana, 2011 [33]

Consent required unless waived by an ethic

is normally the Botswana (MOH SOPs, rearch data. The reats of the data, the Principal

An ethics committee may Investigators and local

sometimes waive, with or institutions in Botswana

without conditions, the should hold the data in

requirement for consent. trust on behalf of the

(MOH SOPs, 2011, 7.2.v) Botswana government

Acquisition, storage and and the research

future use of biological participant. The host

materials: Informed institutions or researcher

consent process and has to apply to the HRDC

forms separate from and regarding the decisions

in addition to informed about use and sharing

consent for research

participation. $(\mathrm{MOH}$

SOPs, 2011, 8.2) of their data with other

researchers and

institutions according to

Botswana law (MOH SOPs,

2011, 8.5.Appendix 11)."
Research protocols should Host institution in

detail the purpose and Botswana is entrusted

use of research specimens custodianship of samples

Where archived

specimens are required in in trust on behalf of

Botswana Government

researchers must provide and the research

a new protocol for review participant. Research

subjects have right to
withdraw their samples if

traceable. Health Research

and Development

Committee approval

required for use, transfer

according to Botswana

laws.

Where samples have not

been obtained as part of

research, the institution

that collected them takes

custodianship of them.

Any future study on such

samples is subject to

review by HRDC. $(\mathrm{MOH}$

SOPs, 2011, 8.2)
No transfer unless: a) the researcher and the other research group are

collaborating on research that has been approved by an ethics committee

and $b$ ) the genetic

material cannot be

identified. Transfer of

identifiable or potentially identifiable genetic material may be approved by HRDC in certain circumstances. ( $\mathrm{MOH}$ SOPS, 2011, 7.2.vi)

\section{All exchanges and} transfers (including importation) of HBS for research purposes shall require clearance from the HRDC. (MOH SOPs, 2011 8.3)

Procedures for Exchange/ Transfer of HB Materials, pg. 112.(MOH SOPs, 2011 , 8.3) 
Table 3 National regulatory guidance language on collection and use of HBS by country* (Continued)

\begin{tabular}{|c|c|c|c|c|c|c|}
\hline $\begin{array}{l}\text { Legislation, regulations, } \\
\text { and/or guidance re. } \\
\text { research and/or HBS }\end{array}$ & Specific HBS language & HBS consent & HBS ownership & HBS secondary use & HBS storage & HBS Import/export \\
\hline \multicolumn{7}{|l|}{ Burkina Faso } \\
\hline $\begin{array}{l}\text { Law No. 23/94/ADP of } 19 \\
\text { May } 1994 \text { on the Code of } \\
\text { Public Health [34] } \\
\text { Décret No. 2002-536 } \\
\text { Established National } \\
\text { Bioethics Committee [35] } \\
\text { Minister of Health, the } \\
\text { Minister of Secondary and } \\
\text { Higher Education and } \\
\text { Scientific Research (2004) } \\
\text { Joint order No. } \\
\text { 2004/147/MS/MESSRS on } \\
\text { the organization and } \\
\text { functioning of the Ethics } \\
\text { Committee for Health } \\
\text { Research in Burkina Faso. } \\
\text { [36] (Decree contains no } \\
\text { research ethics regulatory } \\
\text { guidance.) } \\
\text { A draft Code of Ethics was } \\
\text { written in } 2005 \text { but there } \\
\text { is no publicly available } \\
\text { data indicating it was } \\
\text { operationalized. }\end{array}$ & $\begin{array}{l}\text { Human biological } \\
\text { materials means the } \\
\text { organs, tissues and } \\
\text { products that can be used } \\
\text { for therapeutic or research } \\
\text { purposes on human } \\
\text { beings. They can be } \\
\text { derived from living or } \\
\text { cadaveric donors. (Law } \\
\text { No. 23/94) }\end{array}$ & $\begin{array}{l}\text { Consent required for } \\
\text { human genetic research } \\
\text { unless waived by an } \\
\text { ethics committee. } \\
\text { Institutions or } \\
\text { organizations wishing to } \\
\text { conduct research on } \\
\text { genetic material and on } \\
\text { information collected for } \\
\text { non-research purposes } \\
\text { should develop and } \\
\text { disseminate a general } \\
\text { policy that informs } \\
\text { subjects that such } \\
\text { material and information } \\
\text { may be used for future } \\
\text { research, following } \\
\text { research ethics committee } \\
\text { approval, participants in } \\
\text { such institutions or } \\
\text { organizations should be } \\
\text { informed that this policy } \\
\text { exists and that their } \\
\text { privacy and confidentiality } \\
\text { will be protected. (p. 105- } \\
\text { 106). } \\
\text { Page } 106 \text { specifies } \\
\text { information that must be } \\
\text { contained in a consent } \\
\text { document for a study } \\
\text { involving human genetic } \\
\text { research. (Joint Order No. } \\
\text { 2004) }\end{array}$ & No language & No language & No language & No language \\
\hline \multicolumn{7}{|l|}{ Burundi } \\
\hline None found & None found & None found & None found & None found & None found & None found \\
\hline \multicolumn{7}{|l|}{ Cameroon } \\
\hline Arrêté No. 079/A/MSP/DS- & No language & No language & No language & No language & No language & No language \\
\hline
\end{tabular}

Order of the Minister of

Public Health, October 22,

1987: Creation and

organization of an ethics

committee for research

involving human subjects

[37]

No language
No language
No language
No language 
Table 3 National regulatory guidance language on collection and use of HBS by country* (Continued)

\begin{tabular}{|c|c|c|c|c|c|c|}
\hline $\begin{array}{l}\text { Legislation, regulations, } \\
\text { and/or guidance re. } \\
\text { research and/or HBS }\end{array}$ & Specific HBS language & HBS consent & HBS ownership & HBS secondary use & HBS storage & HBS Import/export \\
\hline \multicolumn{7}{|l|}{$\begin{array}{l}\text { (Article } 9 \text { refers to an } \\
\text { evaluation process relying } \\
\text { on Declaration of Helsinki) } \\
\text { Decision 0674/D/MSP/ } \\
\text { CIRCB, October 13, 2006: } \\
\text { Creation and functions of } \\
\text { an ethics committee in } \\
\text { the Chantal International } \\
\text { Reference Center for } \\
\text { research on the } \\
\text { prevention and treatment } \\
\text { of HIV/AIDS [38] }\end{array}$} \\
\hline \multicolumn{7}{|l|}{ Cape Verde } \\
\hline None found & None found & None found & None found & None found & None found & None found \\
\hline \multicolumn{7}{|l|}{ Central African Republic } \\
\hline None found & None found & None found & None found & None found & None found & None found \\
\hline \multicolumn{7}{|l|}{ Chad } \\
\hline $\begin{array}{l}\text { Part of UNESCO Bioethics } \\
\text { project. Efforts to establish } \\
\text { National Ethics } \\
\text { Commission reported in } \\
\text { meeting report, UNESCO, } \\
\text { 2008) [23] }\end{array}$ & None found & None found & None found & None found & None found & None found \\
\hline \multicolumn{7}{|l|}{ Comoros } \\
\hline None found & None found & None found & None found & None found & None found & None found \\
\hline \multicolumn{7}{|l|}{ Republic of Congo } \\
\hline None found & None found & None found & None found & None found & None found & None found \\
\hline \multicolumn{7}{|l|}{ Congo (DRC) } \\
\hline $\begin{array}{l}\text { Ministry of Health, } \\
\text { Politique nationale de } \\
\text { recherché sure les } \\
\text { systems de santé en RDC } \\
\text { (June 2004) [39] }\end{array}$ & No language & No language & No language & No language & No language & No language \\
\hline \multicolumn{7}{|l|}{ Côte D'ivoire } \\
\hline None found & None found & None found & None found & None found & None found & None found \\
\hline \multicolumn{7}{|l|}{ Djibouti } \\
\hline None found & None found & None found & None found & None found & None found & None found \\
\hline
\end{tabular}


Table 3 National regulatory guidance language on collection and use of HBS by country* (Continued)

and/or guidance re.

HBS consent

HBS ownership

HBS secondary use

HBS storage

HBS Import/export

research and/or HBS

No language

No language

No language

No language

No language

No language

124/2014: Establishes the

National Ethics

Committee of Equatorial

Guinea (CENGE), 2014. [40]

Presidential Decree 125/

2014: Constitute CENGE

and appoints inaugural

members, 2014 [41]

Eritrea

None found

None found

None found

None found

None found

FDRE Ministry of Science \& Technology; National Research Ethics Review Guideline [5th Ed.] Sept. $2014[42]$

National Health Research thics Review Guidelin Guideline 8.3.2, p. 51-52

C process should include Host institution in Ethiopia info on HBS and data to be collected, data

anticipated to be derived participant. (Guideline, 9-2, from sample as well as health and other records to be accessed, their

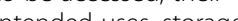
intended uses, storage and duration of storage. Participants must be informed that specific information will not be shared with family

members, and that, if

shared with third parties, will be anonymized.

Participant should be

given option of allowing

sharing of samples or not.

(Guideline, 8.3.2., p. 52)

Separate consent form for

HBS collected for storage

Participant may choose

whether to have HBS

stored for future studies.

(Guideline, 9.2, p. 57) holds HBS in trust on behalf of research

p. 58) Where HBS have

not been obtained as part

of research, the institution

that collected the samples

takes custodianship.

(Guideline 9.2, p. 58)

ny shared samples must be anonymized to the recipient, Use of HBS

beyond what is stated in

original protocol must

have consent of research

participants or their

representatives. Secondary

use may only be done on

anonymized samples and

after getting approval by

the IRB. When subsequen

use of HBS or data is

proposed that is not

consistent with original I/

$C$, a new consent should

be obtained from

participant/guardian or

LAR or a waiver of

consent should be

requested from IRB.

(Guideline, 8.3.2, p. 52)

Gabon

Establishment of a

No language

No language

No language

No language

No language

No language

Committee (UNESCO

2007) [24]

Intent to store HBS and

and duration of

contain details regarding

MTA required. It must
contain details regardin

purpose of transfer/export

arrangements for

collaboration and benefit-

Research

sharing, a framework for

accessing and sharing

data, restrictions to third

party transfers, and annual

n Ethiopian scientist

ine included as a co-

studies using the HBS. The

IRB in Ethiopia must

review all research studies

on stored HBS. (Guideline

9.2 , p. 58 
$\frac{\text { Table } 3 \text { National regulatory guidance language on collection and use of HBS by country* (Continued) }}{\text { Legislation, regulations, Specific HBS language HBS consent }}$ and/or guidance re.

HBS consent

HBS ownership

HBS secondary use

HBS storage

HBS Import/export

research and/or HBS

\section{The Gambia (Republic oF)}

[No national regulatory guidance for general

research although final

drafts exist.]

Dept. of State for Health \&

Welfare; National Health

Research Policy[revised

draft for discussion: 29/10/

2009] [43]

Dept. of State for Health \&

Welfare; National Health

Research Strategic Plan

2010-2014 [final draft: 15/

01/2010] [44]

\section{Ghana}

No research ethics

regulatory guidance

Public Health Act 2012

[Act 851] Good Clinical

Practice Doc No FDA

$\mathrm{SMC/CTD/GL-} \mathrm{GCP/2013/}$

02 Ver. 2, 18 Dec 2015

(Adopted 27 Jan 2016)

[45]

Guinea (Republic of)

Decree No. D/218/PRG/ SGG: On the

Establishment, Functions and Organization of the National Ethics

Committee for Research

in Health (CNERS) (Decree

No D/218). 1998. [46]

Decree contains no ethics

regulatory guidance

language.

Guinea-Bissau

None found 22]

None found None found

Guidelines for The Gambia Samples from children ational DNA Bank, 2001

only after permission from parents or guardians No consent for reuse, but permission of Gambian government/MRC

Laboratories Ethics

Committee is required.

Permission from donor for

reuse of samples that

have not been

anonymized is required in

principle, but committee

can waive this

requirement. (DNA Bank

Guidelines, 2001)
DNA Collections are jointly owned by the Gambian government Medical Research Council (DNA Bank Guidelines, 2001)

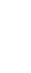
people through their representatives and the

Reuse permissible with approval from Joint Committee. Different levels of permissions/ consents required depending on whether or have been anonymized, collected as part of a specific protocol or available to researchers with approval from Committee only. [DNA Bank Guidelines, 2001]

No language
The Gambia National DNA Permission for export Bank was established in based on signed 2001, the first biobank on agreement between researchers and the DNA Bank, with approval of Committee. Agreement must describe analyses to be undertaken with specimens; feedback must be given to MRC Labs, results of analyses must the public domain, and any manuscripts resulting from research must be submitted to Joint Committee prior to submission. (DNA Bank Guidelines, 2001)

No language 
Table 3 National regulatory guidance language on collection and use of HBS by country* (Continued)

\begin{tabular}{|c|c|c|c|c|c|c|}
\hline $\begin{array}{l}\text { Legislation, regulations, } \\
\text { and/or guidance re. } \\
\text { research and/or HBS }\end{array}$ & Specific HBS language & HBS consent & HBS ownership & HBS secondary use & HBS storage & HBS Import/export \\
\hline \multicolumn{7}{|l|}{ Kenya } \\
\hline $\begin{array}{l}\text { The Science, Technology } \\
\text { and Innovation Act, } 2013 \\
\text { [47] National Council for } \\
\text { Science and Technology } \\
\text { Guidelines for Ethical } \\
\text { Conduct of Biomedical } \\
\text { Research Involving } \\
\text { Human Subjects in Kenya } \\
\text { (NCST No. 45) 2004. [48] } \\
\text { Kenya Medical Research } \\
\text { Institute (KEMRI), National } \\
\text { Ethics Review Committee: } \\
\text { Guidelines and Standard } \\
\text { Operating Procedures, } \\
\text { 2004. [49] } \\
\text { Ministry of Health, } \\
\text { National Guidelines for } \\
\text { Research and } \\
\text { Development of HIV/AIDS } \\
\text { Vaccines, 2005. [50] } \\
\text { Pharmacy and Poisons } \\
\text { Board: Guidelines for } \\
\text { applications to conduct }\end{array}$ & $\begin{array}{l}\text { HBS reference limited to } \\
\text { Guideline } 15 \text { (National } \\
\text { Guidelines, 2004) }\end{array}$ & $\begin{array}{l}\text { Guideline 15. Informed } \\
\text { Consent for } \\
\text { epidemiological studies- } \\
\text { ERC to determine whether } \\
\text { or not individual informed } \\
\text { consent is needed for } \\
\text { studies involving "left- } \\
\text { over" HBS (Natl Guidelines } \\
\text { 2004) } \\
\text { Applications for clinical } \\
\text { trials must include patient } \\
\text { information leaflets and } \\
\text { informed consent forms } \\
\text { for any proposed } \\
\text { archiving of biological } \\
\text { specimens for later } \\
\text { research or genetics } \\
\text { research. (Pharmacy \& } \\
\text { Poisons Board Guidelines, } \\
\text { 2011, Art. 4.12) }\end{array}$ & No language & $\begin{array}{l}\text { Guideline 15. Informed } \\
\text { Consent for } \\
\text { epidemiological studies- } \\
\text { ERC to determine } \\
\text { whether or not individual } \\
\text { informed consent is } \\
\text { needed for studies } \\
\text { involving "left-over" HBS } \\
\text { (Natl Guidelines 2004) }\end{array}$ & No language & $\begin{array}{l}\text { No biological material } \\
\text { transfer is permitted } \\
\text { without the informed } \\
\text { consent of the trial } \\
\text { participants and without } \\
\text { approval of protocol and } \\
\text { in accordance to Ministry } \\
\text { of Health guidelines on } \\
\text { transfer of HBS. (Vaccine } \\
\text { guideline } 7.3, \text { p. } 44 \text { 2005) } \\
\text { MTAs govern all } \\
\text { transferred materials and } \\
\text { specimens used for } \\
\text { vaccine studies. MTAs } \\
\text { must state that specimens } \\
\text { will only be used for } \\
\text { scientific, educational, } \\
\text { non- commercial use. Any } \\
\text { other uses require a } \\
\text { cooperative research and } \\
\text { development agreement } \\
\text { (RADA). (Vaccine } \\
\text { Guidelines, } 8.3,2005 \text { ) }\end{array}$ \\
\hline
\end{tabular}

chical trials in Kenya,

2011. [50]

Lesotho

Ministry of Health and

Health and Social Welfare

Research Policy (NHSWRP),

Lesotho. 2007.[51]

(Established a National

Health and Social Welfare

Research Ethics and

Clearance Committee

within the National

Research Institute at the

MoHSW.)

No research ethics

regulatory guidance. 
Table 3 National regulatory guidance language on collection and use of HBS by country* (Continued)

and/or guidance re.

HBS consent

HBS ownership

HBS secondary use

HBS storage

HBS Import/export

\section{Liberia}

Ethics approval required

from one of three REC

bodies: Liberia Institute of

Biomedical Research/

Research involving the collection or study of

or diagnostic specimens

may be exempt, if those

sources are publicly

NHSREC), the University of available or if the

Liberia Institutional

information is recorded

Review Board (UL- IRB), or by the investigator in

the newly established such a manner that the

National Research Ethics subjects cannot be

Board (NREB). [52]

identified, directly or

Unversity of Liberia-Pacific indirectly, through

Evaluation: Institutional identifiers

and Procedures t

2008 [53] Liberia Medicines potentially be identified is

and Health Products

not exempt. (University of

Regulatory Authority,

Liberia, Policies \&

Grideline for Application Procedures Handbook

to Conduct Clinical Trials in 2008, Art. 5 pg. 23)

Liberia 2014. [54]

\section{Madagascar}

Decree No. 5855/99-SAN No language

(June 17, 1999) modified

by Decree No. 4583/2000-

SAN (May 8, 2000)

(Created a National Ethical

Committee for Biomedical

Research.)

Documents contain no

research ethics regulatory

guidance. [55]
Applications for clinical

trials must include patient

information leaflets and

informed consent forms

for any proposed

archiving of biologica

specimens for later

research or genetics

research. (LMHRA

Guidelines, 2014, Art.

4.12 .5 p. 14)

Materials Transfer

Agreement must be

provided to the Liberia

Medicines and Health

Products Regulatory

Authority's (LMHRA)

(LMHRA Guidelines, 2014.) 
$\frac{\text { Table } 3 \text { National regulatory guidance language on collection and use of HBS by country* (Continued) }}{\text { Legislation, regulations, Specific HBS language HBS consent }}$

and/or guidance re.

HBS consent

HBS ownership

HBS secondary use

HBS storage

HBS Import/export

research and/or HBS

\section{Malawi}

National Health Sciences

Research Committee:

General Guidelines on

Health Research

(December 2007) [56]

National Health Sciences

Research Committee,

Policy Requirements,

Procedures, and

Guidelines for the

Conduct and Review of

Human Genetic Researc

in Malawi (September

2012) [23]

National Commission for

Science and Technology

(2012). National Policy

measures and

Requirements for the

Improvement of Health

Research Coordination in

Malawi (Revised ed., 11/

2012). [57]

Mali

No. 02-200/P-RM April 22, No language

2002- ustification for the

required. Persons may

collection and exporting only be consented for

of biological samples will HBS collection for

ave to be made.

purposes of answering

General Guidelines, 2007, the study objectives of a

section 6.1)

presently intended study

BSS language contained that has been clearly

in 2007 and 2012 defined.(Policy

documents.

defined.(Policy

Requirements, 2007, 10.0)
Clear explanation and Informed consent for HBS No language

Creation of a National

Ethics Committee fo

Health and Life Sciences

[58]

Minister of Health-

Internal Ruling August 26,

2004- Operation and

Functions of Ethics

Committee for Health and

Life Sciences. [59] Loi 86-

11 N RM Fundamenta

Principles of Scientific and

Technological Research

[60] (Documents contain

no ethics guidance for

conduct of research.)
All forms of studies \&

testing aimed at

collecting and storing $H B S$

for future unspecified

genetic research/analysis,

including scientific

retrospective analysis is

non- permissible (HBS

Guidelines, 2012, 3.4.7)

Plans, attempts, requests

for obtaining HBS for

future research non-

Guidelines, 2012 3.4.8)

(1)

No language

No language

No language

No language

should be done within

clearly defined. (General Malawi by local

Guidelines, 2007, Section technicians/professionals.

Not permissible to

consent participants to when the needed

collection, use, storage of technology does not exist

specimens for future use, in Malawi nor can it be

HBS may be stored for imported or when tests

ysis as specified are needed to confirm

results and/or quality

tentrol and validation are

but not for a period to required.(Policy

Requirements, 2007, 10.0)

Additional time period

MTAs are required.

may be granted. (Policy Agreement must clearly

Requirements, 2007, 10.0)

Agreement must clearly
specify why export is

necessary, its intended

use, length of time HBS
will be kept, and name of

local technician/

professional who will be

responsible for HBS

testing.(Policy

Requirements, 2007, 10.0)

No language 
Table 3 National regulatory guidance language on collection and use of HBS by country* (Continued)

(1) and/or guidance re.
research and/or HBS

Organization and

functions of the National

Institute of Public Health

Research, including

establishment of an ethics

committee within

Institute) [61]

Mauritania

\section{None found \\ Mauritius}

The Clinical Trials Bill (Feb

11, 2010)- calls for Ethics

Committee to uphold

International Ethics

provisions while
respecting customs and

values of country. [62]

Mauritius Research

Council (MRC) drafted

ethics guidelines for

biomedical research

involving human subjects

in July 2003 and they

remain out for public

comment. No on-line

evidence that final

guidelines have been

approved.

Mozambique

Order May 21, 2002-

Minister of health

established National

Research Ethics Committee

[63] No specific laws on

research involving human

beings. National ERC

(CNBS-Comité national de

Bioética para Saude)

applies international

principles (Dec. of Helsinki,

CIOMS, ICH-GCP.)
None found

None found

None found

No language

No language

No language

found

No language 
\begin{tabular}{l} 
Table 3 National regulatory guidance language on collection and use of HBS by country* (Continued) \\
\hline Legislation, regulations, Specific HBS language HBS consent
\end{tabular}

and/or guidance re.

HBS consent

HBS ownership

HBS secondary use

HBS storage

HBS Import/export

research and/or HBS

\section{Namibia}

Ministry of Health and

Social Sciences has

None found

None found

None found

None found

None found

None found

constituted a Biomedica

Research Ethical

Committee but it is not

operational. [64]

Niger

None found

None found

None found

None found

None found

None found

None found

Nigeria

National Health Research Reference to HBS in

connection with MTAs

(Ethics Code, 2007)

Biobanks in Nigeria must No language

No language _ No language

Nigeria (NHREC) Nationa

Code of Health Research

Ethics 2007. [65]

Policy Statement on

Storage of Human

See Bioban

provide sole oversight of

No

consent forms and these

must be matched to all

samples in biobanks

(Section D,iii,a., Biobanks,

2013) NHREC supports

Broad Consent- consent

in which the type or

purpose of research is

defined in broad terms

and for a work that is not

specified by time (Section

E.1, Biobanks, 2013)

Rwanda

Rwanda Ministry of Health, National Research

Ethics Committee:

Standard Operating

Procedures, 2009 [67]

Rwanda Ministry of

Health, National Health

Research Committee

Operational Guidelines,

2012. [68]

Regulations with respect

to HBS (Sections 35 \& 36

of Rwanda Ministry of

Health Standard

Operating Procedures,

009

HBS must be collected

with free and informed

consent even if tissue is

obtained as part of

Under MTAs: Ownership is No language

the "Provider of the

samples." Ownership

of any income resulting from

patient care. Consent commercialization must

orms must indicate if HBS be negotiated in good

is being collected for

faith (Rwanda SOPs, 2009,

current research only, Appendix 7).

how long the specimens

will be kept, and when

they will be destroyed. If

HBS is stored longer than

the current research, then

a separate permission for

storage must be obtained.

Any samples kept more

analysis are considered

'banked' and covered by

Biobank Policy. Copies of

all participant I/C forms

must be available and can
be matched to samples

be matched to samples

(Biobank Policy 2013)

to whom HBS is

transferred must provide

any resultant publications,

and provider must be part

of the publication team

(Rwanda SOPs, 2009,

Appendix 7 
$\frac{\text { Table } 3 \text { National regulatory guidance language on collection and use of HBS by country* (Continued) }}{\text { Legislation, regulations, Specific HBS language HBS consent }}$

and/or guidance re.

HBS consent

HBS ownership

HBS secondary use

HBS storage

HBS Import/export

research and/or HBS

Sao Tome \& Principe

None found

None found

None found

None found

None found

None found

None found

Senegal

Arrêté ministerial No. 3224 No language

MSP- DERF-DER, March 17,

No language

No language

No language

No language

No language

2004: Creation and

organization of National

Council for Health

Research (CNRS) [69]

Loi No. 2009-17, March 9,

2009:

Code of Ethics for Health

Research. [70]

Règlement Intérieur du

Conseil National de la

Recherche en Santé

[Standard Operating

Procedures], March 7

2006. [71]

Seychelles

None found

None found

None found

None found

None found

None found

Pharmacy Board of Sierra

Leone: Guidelines for

Section 3.9 Biological

specimens/samples

Separate consent for use No language of HBS (Guidelines, 2014

of Medicines, Food

(Guidelines for conducting

Supplements, Vaccines,

and Medical Devices in

Sierra Leone (Version 02)

Pharmacy Board of Sierra

Leone: Guideline for Good

clinical care may be used

for research without

biological specimen or a consent subject to ethics

biological sample is committee review.

defined as material Patients have right to

derived from various know their HBS is being

Clinical Practice (GCP) in

animal and human

used for research. Patien

sources (e.g., blood,

refusal to such use does

tissues, and cells) used to

treat and prevent

not warrant waiver of

Sanitation, Office of the

diseases. (Guidelines for

Sierration, Ofice of the

Scientific Review

Committee: Sierra Leon

Ethics and Scientific

GCP, 2014)

Refusals to be honored

except in case of public

health emergency.

(Guidelines, 2014, Sec.

3.9.2

Secondary use of HBS is No language

constrained by conditions

specified in initial consent

Therefore, initial consent

should specify whether or

not there will be

secondary use; conditions

under which subjects

must be re-contacted

plans, if any, for de-

identification; and subject

rights. (Guidelines, 2014,

Sec. 3.9.3) 
Table 3 National regulatory guidance language on collection and use of HBS by country* (Continued)
Legislation, regulations, Specific HBS language HBS consent and/or guidance re.

HBS ownership

HBS secondary use

HBS storage

HBS Import/export

research and/or HBS

\section{Somalia}

None found

None found

None found

None found

No language

Act 61 of 2003 National Health Act [75]

Regulations Relating to

the Use of Human

Chapter 8, Sections 53-68. Written informed consent

of individual with provisions

2003) Regulations Relating for consent from subjects

to the Use of HBS (2012)

who are minors or mentally

ill (Regulations, 2012, 3.1)

Written informed consent

by users/donors for

release of stored

information and for long-

term storage of genetic

material, stem cells, or

research findings

(Regulations, 2012, 13.d \& f).

South Sudan

None found

None found

None found

None found

No language

$\begin{array}{ll}\text { Guidelines, 2008, Secs. 5.2, } & \text { Investigator must provide } \\ \text { 5.10, \& 5.11). } & \text { subjects: policy to use results }\end{array}$

National Guidelines for

Ethical Conduct of

Research Involving

Human Subjects (2008)

[77] of genetic tests and familial

genetic information and

precautions to prevent

disclosure to others

(Guidelines, 2008, 5.2.16);

possible research sites, direc

or secondary use of HBS

taken in course of clinical

care (5.2.18); disposal, storage,

future use of HBS (5.2.19)

any commercial products

from HBS and distribution of

any revenues (Guidelines,

2008, 5.2.20) Consent forms

must have separate section

requesting use of $\mathrm{HBS}$ for

research purposes

(Guidelines, 2008, 5.10)

HBS taken in course of

clinical care may be used

w/o consent subject to

approval of ethics

committee (Guidelines,

$2008,5.11)$.
None found

None found

None found

HBS information used for Written informed consent Export permit is required. purposes for which it was of the user or donor for No export unless it is

originally intended.

(Regulations, 2012, 13.e).

genetic materi

was donated under terms

the of Act and will be used in

HBS information treated accordance with terms of

confidentially.

Users' written informed

consent prior to release of

stored information.

(Regulations 2012, 13e \& f). Act. (Act, 2003, 8.68.1(g))

None found

None found

None found

Constrained by conditions No language

specified in original

No language 
Table 3 National regulatory guidance language on collection and use of HBS by country* (Continued)
Legislation, regulations, Specific HBS language HBS consent and/or guidance re.

HBS consent

HBS ownership

HBS secondary use

HBS storage

HBS Import/export

research and/or HBS

Swaziland

None found

None found

None found

None found

None found

None found

None found

TANZANIA

National Institute for

1979 [78

Part V Human DNA

Research Activities,

Medical Research \&

Guidelines of Ethics for

Health Research in

Tanzania, 2nd ed., 2009.

[24]

The Human DNA

Regulations Act, 2009 [79]

Standard Operating

Procedures for the

National Health Research

Ethics Review Committee,

2007 [80]

Togo

None found

None found

None found

None found

Consent for intended

are the property of the

study only. New proto

sample source. (DNA Act,

(Guidelines, 2009, 8.8)

(28, 2b)

No collection of a sample Where the research results

without the

consent of the sample

source (DNA Act,

2009, 38-41).

from an individual or an

institute are new or

unique, the researcher or

the institute shall have the

intellectual property rights

(DNA Act, 2009, 5.3.7).

Consent for intended

study only New protocol

required for reuse (8.8,

Guidelines, 2009)

Sample destroyed on

completion of analysis

unless sample source's

representative has

previously directed

therwise in writing (DNA

Act, 2009, 28.2.e)

After completion of

original research,

investigators must (a)

within one month notify

of their intent to reuse

and secure the permission

of sample source or (b)

destroy samples within

three months (38.44, DNA

Act, 2009, 38.44)

None found

None found

A Ugandan scientist must See HBS I/C be included on all future studies. Separate informed

consent document

explanation of how

Sample sources own the

Health, National Health

Policy, 1999 [81]

Uganda National Counci

for Science and

Technology (NCST),

National Guidelines for

Research Involving

Humans as Research

Participants, July 2014

[82] will be mana

of study. If stored,

identified, source may

withdraw them at any

separate consent must be time. Samples to be held

obtained, with purpose of in trust by duly authorized

study, quantities stored, Uganda organization.

location, measures to Trustee organization has

ensure confidentiality,

and potential benefits.

(Guideline, 2014, 5.3.h)

transfer, storage and

care taking into account
(See HBS, I/C). All future

studies subject to REC

review. If samples

collected initially for

purposes other than

research, sample sources

must be traced and

rights and welfare of

consent for research use

research participants

secured. (Guidelines,2014

10.2)

Materials transfer

agreement is required.

(Guidelines, 2014, 10.3)

MTA required. Future use of HBS subject to review and approval by an REC in provider's country.

(Guideline, 2014, 10.4)

Applicant for transfer must be a legal resident of

Uganda and affiliated with

a locally registered and

recognized Uganda

organization. (Guidelines

2014, 10.5)To export,

requesting entity must

demonstrate lack of in-

country capacity to

perform tasks. Sample may

be transferred for quality 
\begin{tabular}{l} 
Table 3 National regulatory guidance language on collection and use of HBS by country* (Continued) \\
\hline Legislation, regulations, Specific HBS language HBS consent
\end{tabular}

and/or guidance re

HBS ownership

HBS secondary use

HBS storage

HBS Import/export

research and/or HBS

If MTA doesn't specify

ownership of future

products, they are

automatically owned by

provider organization.

(Guidelines 2014, 10.5)

\section{Zambia}

The National Health

Research Act 2013 [83]

May only be collected for

purposes stated in research protocol (Act,

Part VI)

Minister of Health may

designate specific sites as

biobanks

HBS removed from living person for health research purposes without written consent of donor accordance with

Ownership specified in MTA as determined by provisions of the Act. Acti consult with Health Art. 47 (1)
A person shall not withdraw HBS from living person for any unspecified future health esearch activity of unspecified storage. Act Art. 47 (2)

No language

assurance and laboratory reference purposes. All

exchanges and transfers require approval of NCST except exchanges within country.

Capacity-building by requesting organization encouraged. (Guidelines, 2014, 10.4)

A person shall not withdraw HBS from a living person for any unspecified future health research activity or of the National Health Research Authority Act, Art 50 (1) and if terms of Act, MTA are met Art. 50 (2) Art. 47 (2) Storage not to exceed Authority, decides on 10 years without special approval of longer period from Health Authority Act, Art. 51 (2) (b)

Zimbabwe

Scientific Technological Discussion of HBS not included in MRCZ

No language

No language

Extraterritorial storage of

Export for specified

Act) (Ch. 10:22), 1986

guidelines.

(Replaced Research Act

1959) [84]

Medical Research Council

of Zimbabwe: Ethics

Guidelines for Health

Research Involving

Human participants in

Zimbabwe, Version 1.4,

September 30, 2011 [85]

Research Council of

Zimbabwe (RCZ):

Specimens Transfer

Agreement (STA) (online

as of $1 / 3 / 15)[86]$

* Guidance language cited verbatim where possible. biospecimens beyond

Research Council of

Zimbabwe approval No third party transfers.

period is illegal. RCZ STA, Specimens Transfer

2015) Agreement (STA) is

required.

studies must be registered

with RCZ. 
Table 4 Clinical trials in SSA involving HBS collection (Source: WHO-ICTRP as of January 1, 2015)

\begin{tabular}{|c|c|c|c|c|c|c|c|}
\hline Country & $\begin{array}{l}\text { Total \# } \\
\text { studies }\end{array}$ & $\begin{array}{l}\text { Total active } \\
\text { recruiting/Not } \\
\text { yet recruiting }\end{array}$ & $\begin{array}{l}\text { Total active not } \\
\text { recruiting }\end{array}$ & $\begin{array}{l}\text { Total active } \\
\text { studies }\end{array}$ & $\begin{array}{l}\text { HBS collection } \\
\text { active recruiting/ } \\
\text { Not yet recruiting }\end{array}$ & $\begin{array}{l}\text { HBS collection } \\
\text { active not } \\
\text { recruiting }\end{array}$ & $\begin{array}{l}\text { Total trials } \\
\text { collecting HBS }\end{array}$ \\
\hline Angola & 3 & 2 & 0 & 2 & 2 & 0 & 2 \\
\hline Benin & 33 & 10 & 1 & 11 & 2 & 1 & 3 \\
\hline Botswana & 50 & 10 & 5 & 15 & 4 & 1 & 5 \\
\hline Burkina Faso & 117 & 20 & 11 & 31 & 3 & 1 & 4 \\
\hline Burundi & 0 & 0 & 0 & 0 & 0 & 0 & 0 \\
\hline Cameroon & 57 & 12 & 6 & 18 & 1 & 1 & 2 \\
\hline Cape Verde & 0 & 0 & 0 & 0 & 0 & 0 & 0 \\
\hline $\begin{array}{l}\text { Central } \\
\text { African Rep. }\end{array}$ & 6 & 5 & 3 & 8 & 0 & 0 & 0 \\
\hline Chad & 0 & 0 & 0 & 0 & 0 & 0 & 0 \\
\hline Comoros & 0 & 0 & 0 & 0 & 0 & 0 & 0 \\
\hline Republic of Congo & 59 & 10 & 3 & 13 & 3 & 0 & 3 \\
\hline Congo (DRC) & 17 & 10 & 2 & 12 & 1 & 0 & 1 \\
\hline Cote d'Ivoire & 37 & 10 & 4 & 14 & 3 & 0 & 3 \\
\hline Djibouti & 0 & 0 & 0 & 0 & 0 & 0 & 0 \\
\hline $\begin{array}{l}\text { Equatorial } \\
\text { Guinea }\end{array}$ & 0 & 0 & 0 & 0 & 0 & 0 & 0 \\
\hline Eritrea & 1 & 0 & 0 & 0 & 0 & 0 & 0 \\
\hline Ethiopia & 74 & 22 & 7 & 29 & 2 & 3 & 5 \\
\hline Gabon & 34 & 5 & 0 & 5 & 1 & 0 & 1 \\
\hline The Gambia & 79 & 11 & 4 & 15 & 5 & 1 & 6 \\
\hline Ghana & 138 & 33 & 7 & 40 & 10 & 1 & 11 \\
\hline Guinea & 74 & 1 & 2 & 3 & 0 & 0 & 0 \\
\hline Guinea-Bissau & 43 & 5 & 9 & 14 & 2 & 5 & 7 \\
\hline Kenya & 320 & 65 & 27 & 92 & 17 & 4 & 21 \\
\hline Lesotho & 0 & 0 & 0 & 0 & 0 & 0 & 0 \\
\hline Liberia & 7 & 1 & 1 & 2 & 0 & 0 & 0 \\
\hline Madagascar & 12 & 1 & 0 & 1 & 1 & 0 & 1 \\
\hline Malawi & 171 & 33 & 15 & 48 & 7 & 4 & 11 \\
\hline Mali & 101 & 20 & 7 & 27 & 7 & 3 & 10 \\
\hline Mauritania & 5 & 3 & 0 & 3 & 0 & 0 & 0 \\
\hline Mauritius & 9 & 2 & 1 & 3 & 0 & 0 & 0 \\
\hline Mozambique & 52 & 11 & 1 & 12 & 2 & 1 & 3 \\
\hline Namibia & 0 & 0 & 0 & 0 & 0 & 0 & 0 \\
\hline Niger & 19 & 7 & 1 & 8 & 2 & 0 & 2 \\
\hline Nigeria & 103 & 37 & 7 & 44 & 10 & 2 & 12 \\
\hline Rwanda & 57 & 8 & 1 & 9 & 2 & 0 & 2 \\
\hline $\begin{array}{l}\text { Sao Tome \& } \\
\text { Principe }\end{array}$ & 0 & 0 & 0 & 0 & 0 & 0 & 0 \\
\hline Senegal & 58 & 10 & 3 & 13 & 2 & 0 & 2 \\
\hline Seychelles & 2 & 0 & 1 & 1 & 0 & 1 & 1 \\
\hline Sierra Leone & 11 & 3 & 3 & 6 & 1 & 2 & 3 \\
\hline Somalia & n.d. & n.d. & n.d. & n.d. & n.d. & n.d. & n.d. \\
\hline South Africa & 2712 & 832 & 234 & 1066 & 150 & 39 & 189 \\
\hline
\end{tabular}


Table 4 Clinical trials in SSA involving HBS collection (Source: WHO-ICTRP as of January 1, 2015) (Continued)

\begin{tabular}{|c|c|c|c|c|c|c|c|}
\hline South Sudan & 0 & 0 & 0 & 0 & 0 & 0 & 0 \\
\hline Sudan & 0 & 0 & 0 & 0 & 0 & 0 & 0 \\
\hline Swaziland & 7 & 4 & 0 & 4 & 1 & 0 & 1 \\
\hline Tanzania & 263 & 45 & 14 & 59 & 10 & 3 & 13 \\
\hline Togo & 8 & 5 & 0 & 5 & 0 & 0 & 0 \\
\hline Uganda & 351 & 74 & 25 & 99 & 20 & 4 & 24 \\
\hline Zambia & 147 & 31 & 11 & 42 & 5 & 4 & 9 \\
\hline Zimbabwe & 82 & 23 & 5 & 28 & 7 & 2 & 9 \\
\hline Total & 5319 & 1381 & 421 & 1802 & 283 & 83 & 366 \\
\hline
\end{tabular}

No data (n.d.)

Gambia and Uganda) spoke to issues of ownership. After Mali, Zimbabwe offered the least guidance within this group of countries, with no language on HBSspecific consent, ownership, or reuse.

\section{Discussion}

This study examined the availability of national ethics and regulatory guidance on biomedical research in SubSaharan African countries and identified the extent to which national regulatory systems provided ethics guidance on specific aspects of HBS collection and use to inform research design and ethics review. Ethical principles and regulatory guidance regarding HBS consent, ownership, reuse, storage, and export/import/transfer are foundational elements in national health systems as research activities calling for the collection and use of biospecimens in Africa expand and ethics committees are increasingly called on to review and respond to rapidly advancing innovation in research and research technologies.

Our research found that despite efforts at the international, regional, and national levels, 20 of the countries in Sub-Saharan Africa (41 \%) at the time of our study still lacked articulated national ethical principles and regulatory guidance for policy-making, review, and monitoring of research. Among those countries where ethical and regulatory guidance existed, specific language with respect to HBS collection and use was often lacking or incomplete. While in 17 of the countries in Sub-Saharan Africa

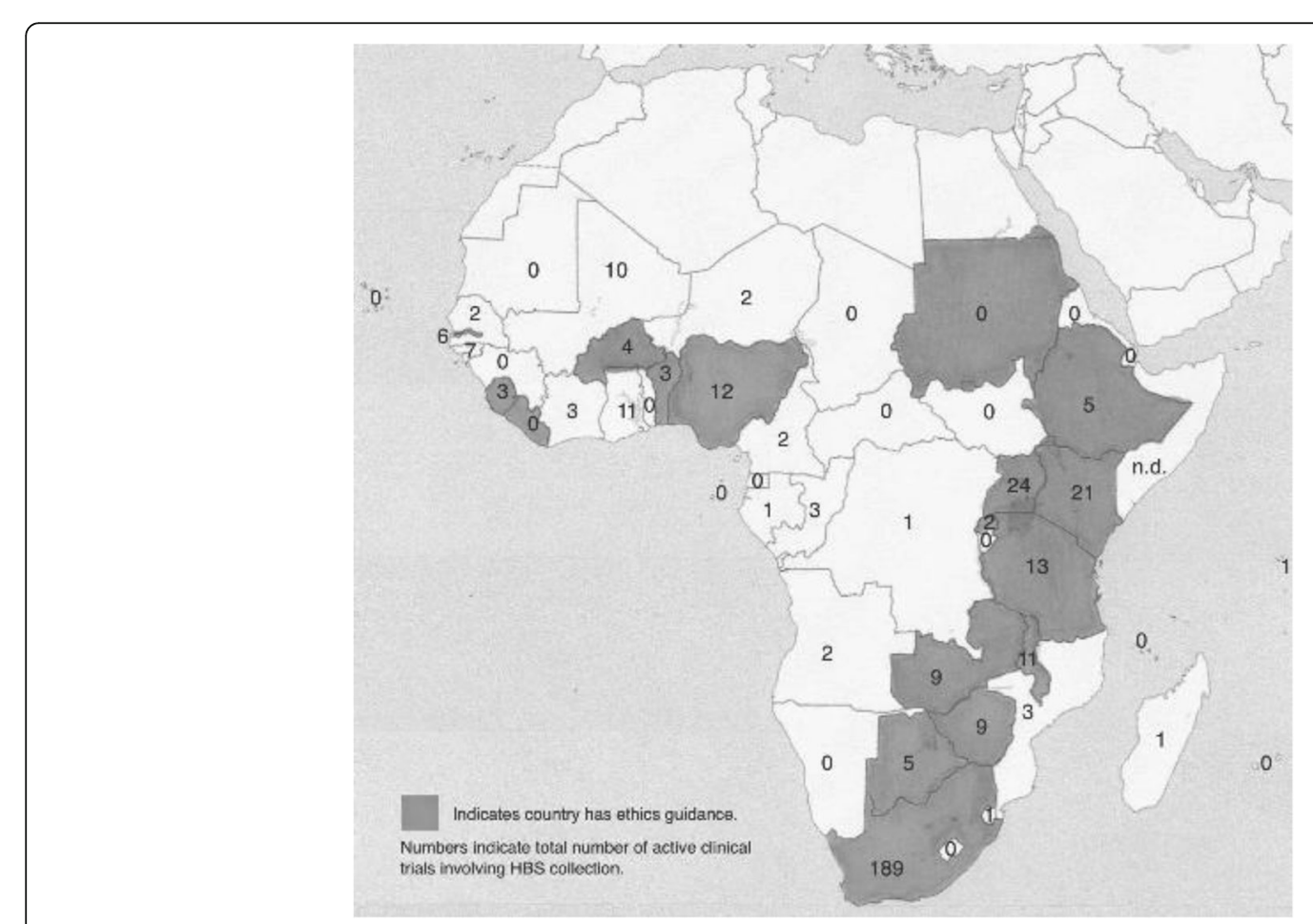

Fig. 2 Distribution of active clinical trials in SSA involving HBS collection (Trial information Source: WHO-ICTRP as of January 1, 2015; Map source: Wikimedia Commons) 
Table 5 National ethics guidance on 10 countries host to the most registered clinical trials

\begin{tabular}{|c|c|c|c|c|c|c|c|c|c|c|c|}
\hline \multirow[t]{2}{*}{ Country } & \multirow{2}{*}{$\begin{array}{l}\text { \# Active } \\
\text { studies } \\
\text { w/HBS }\end{array}$} & \multirow{2}{*}{$\begin{array}{l}\text { Existing } \\
\text { biobanks }\end{array}$} & \multirow{2}{*}{$\begin{array}{l}\text { H3Africa } \\
\text { regional } \\
\text { biobanks }\end{array}$} & \multirow{2}{*}{$\begin{array}{l}\text { Ethics system } \\
\text { guidance } \\
\text { (Gen'l) }\end{array}$} & \multirow{2}{*}{$\begin{array}{l}\text { Ethics system } \\
\text { HBS language }\end{array}$} & \multicolumn{6}{|c|}{ Ethics system guidance specific to HBS } \\
\hline & & & & & & Consent & Ownership & Reuse & Storage & Export & $\overline{\text { MTA }}$ \\
\hline South Africa & 189 & $\bullet$ & $\bullet \bullet$ & $\bullet$ & $\bullet$ & $\bullet$ & & $\bullet$ & $\bullet$ & $\bullet$ & $\bullet$ \\
\hline Uganda & 24 & & $\bullet$ & $\bullet$ & $\bullet$ & $\bullet$ & $\bullet$ & $\bullet$ & $\bullet$ & $\bullet$ & $\bullet$ \\
\hline Kenya & 21 & & & $\bullet$ & $\bullet$ & $\bullet$ & & $\bullet$ & & $\bullet$ & \\
\hline Tanzania & 13 & & & $\bullet$ & $\bullet$ & $\bullet$ & $\bullet$ & $\bullet$ & $\bullet$ & & $\bullet$ \\
\hline Nigeria & 12 & & $\bullet$ & $\bullet$ & $\bullet$ & $\bullet$ & & & $\bullet$ & $\bullet$ & $\bullet$ \\
\hline The Gambia & 11 & $\bullet$ & & $\bullet$ & $\bullet$ & $\bullet$ & $\bullet$ & $\bullet$ & $\bullet$ & $\bullet$ & $\bullet$ \\
\hline Malawi & 11 & & & $\bullet$ & $\bullet$ & $\bullet$ & & $\bullet$ & $\bullet$ & $\bullet$ & $\bullet$ \\
\hline Mali & 10 & & & $\bullet$ & & & & & & & \\
\hline Zambia & 9 & & & $\bullet$ & $\bullet$ & $\bullet$ & $\bullet$ & $\bullet$ & $\bullet$ & $\bullet$ & $\bullet$ \\
\hline Zimbabwe & 9 & $\bullet$ & & $\bullet$ & $\bullet$ & & & & $\bullet$ & $\bullet$ & $\bullet$ \\
\hline Total & 309 & 3 & 4 & 10 & 9 & 8 & 4 & 7 & 8 & 8 & 8 \\
\hline
\end{tabular}

(59\%), some form of national regulatory guidance relating to HBS did exist, a number of these lacked explicit guidance on HBS-related issues such as consent (3), ownership (11), reuse (7), storage (8), and export/import/transfer (5).

Gaps in national ethical and regulatory guidance in the region on the collection and use of HBS for research may result in inconsistent reviews within ethics committees and pose challenges for full participation by African countries in genomic research. In the absence of guiding principles and regulatory direction, ethics committees may delay or deny HBS-related research of potential benefit to their communities, or they may approve such research without due exploration of its implications for its citizenry or its cultural values.

Differences in ethical and regulatory requirements among African countries where guidance does exist also appear to raise impediments to the interoperable pan-African approach to genomic research espoused by H3Africa. Despite the fact that the bulk of registered clinical trials involving HBS in Sub-Saharan Africa, as well as existing sites and those sites proposed for future biorepositories, are currently situated in countries with the most complete ethics and regulatory guidance on $\mathrm{HBS}$, variability in the regulations themselves may create challenges for pan-African collaborations that rely on transnational sharing of specimens and data or that delegate decision-making responsibility with respect to future use to repository-centric ethics or scientific review committees. Malawi, for example, contained language in its guidelines that all forms of studies and testing aimed at collecting and storing HBS for future unspecified genetic research/analysis is 'non-permissible' [25]. Tanzania required that a new consent be secured for each new research protocol in which a sample will be reused [26]. Uganda, where one of the H3Africa repositories is intended to be located, required that all requests for transfers of HBS be made by a legal resident of Uganda who was affiliated with a locally registered and recognized Ugandan organization [27].

While these and other potential sources of regulatory tension may be resolved in the future, for now they represent potential constraints on research that calls for a more 'regional' perspective of specimen and data sharing, and are likely to require legislative action at the national level to revise. At the same time, gaps in HBS-related guidance within countries that are already research-intensive sites may give rise to lengthy or inconsistent review decisions by local ethics committees left to make their own policy decisions in the absence of clearly stated regulations or principles at the national level.

Future growth in the fields of pharmacogenetics and genomic research is likely to generate demand for HBS from a more representative pool of the African peoples and to prompt researchers to look for new communities in countries where research is currently not active. The transnational movements of diseases themselves, as seen in the 2014 Ebola outbreak in Western Africa, may identify new target populations for study beyond those of interest at present. Such expansion will require system-wide capacitybuilding in these settings and will need to be guided by clearly articulated national regulatory guidance to ensure ethical and thoughtful research governance.

Resources to assist national governments in developing ethics capacity may be available through such programs as UNESCO's Assisting Bioethics Committees (ABC) program, which aims to build and strengthen bioethics infrastructure within its member states and which is already working to build capacity in Chad, Gabon, and Madagascar [23, 24, 28]. H3Africa's working group on ethics and regulatory issues and its work to date in articulating broad principles and regulatory guidance regarding HBS collection and use [6] would, were its focus to extend beyond its own funded 
research networks and programs, be a valuable starting point for countries as they begin to build national consensus on the value of genomics research for their communities and the region as a whole.

\section{Limitations of this study}

Data used in this study were largely derived from publicly accessible sources. Despite an extensive search, some of the countries in Sub-Saharan Africa that we report as lacking national ethics regulatory guidelines may, in fact, have them. Given the central role that national policies play in shaping the research landscape in the region, it is important that researchers and ethics committees have ready access to country-level guidance on the collection and use of HBS as the scope of genomics research in Sub-Saharan Africa expands. In addition, the mapping of active clinical trials that involve HBS in SubSaharan Africa relied on publicly accessible international registries. It therefore did not take into account those studies which are not required to register, and serves more as an illustration of a potential regulatory 'gap' between research and national governance than as a comprehensive source of data on HBS-related research in the region.

\section{Conclusion}

Despite substantial capacity-building efforts, many countries still lack regulatory guidance on the collection and use of human biological specimens in research. Although the African countries currently most in demand as HBS-related clinical research sites number among those offering the most guidance, extensive health system strengthening will be needed to ensure that regulatory language is available to guide the ethical extension of HBS-related research into other countries in the region. Efforts to create interoperability across national policies to meet international and regional research goals of Pan-African research collaboration must be on-going, recognizing that some differences may be value-based choices by representative governments while others, although malleable to change, will require legislative action to amend.

\section{Acknowledgements}

Three undergraduate research assistants were made available for this project through the Rutgers University Aresty Research Assistant Program: Madison Little (co-author), Ogechukwu Erechukwu, and Ankita Tripathi. Each of them had an important contribution to make during the data collection phase of this project.

\section{Funding}

Not applicable.

\section{Availability of data and materials}

All data relevant to the analysis of regulatory information is accessible using the links provided in the references for this manuscript. All data used in the analysis of current clinical trials in Africa registered on clinicaltrials.gov are available through that web site.

\section{Authors' contributions}

FB conceptualized the project on which this manuscript is based, designed the methodology, participated in data collection, analyzed the findings, and drafted the original manuscript. MTL had the lead in data collection, assisted in the organization of findings, and read and commented on draft versions of the manuscript. Both authors read and approved the final version of the manuscript.

\section{Competing interests}

The authors declare that they have no competing interests.

\section{Consent for publication}

All authors consent to the publication of this manuscript.

Ethics approval and consent to participate

Not applicable.

\section{Author details}

'Edward J. Bloustein School of Planning and Public Policy, Rutgers University-New Brunswick, 33 Livingston Street, New Brunswick, NJ 08901, USA. ${ }^{2}$ Department of Social Policy \& Intervention, University of Oxford, Oxford, UK.

Received: 20 October 2015 Accepted: 11 October 2016

Published online: 22 October 2016

\section{References}

1. Sirugo G, van der Loeff S, Sam O, Nyan O, Pinder M, Hill AV, et al. A national DNA bank in The Gambia, West Africa, and genomic research in developing countries. Nat Genet. 2004;36:785-6. doi:10.1038/ng0804-785.

2. Matimba A, Oluka MN, Ebeshi BU, Sayi J, Bolaji OO, Guantai Al, et al. Establishment of a biobank and pharmacogenetics database of African populations. Eur J Hum Genet. 2008;16:780-3. doi:10.1038/ejhg.2008.49.

3. University of Kwazulu-Natal African Center for Health and Populations Studies http://www.africacentre.ac.za/index.php/data-rep.

4. Human Heredity and Health in Africa (H3Africa) http://www.h3africa.org/. Accessed 10 Oct 2015

5. Bruinenberg M, Frey M, Napier M, Summers A. Comparing the hub-and-spoke model practices of the LifeLines study in the Netherlands and the H3Africa Initiative. Biopreserv Biobank. 2014;12:13-6. doi:10.1089/bio.2013.0057.

6. H3Africa. Terms of reference for the Ethics and Regulatory Issues Working Group. http://h3africa.org/consortium/working-groups/24-working-groupexternal-pages/128-tor-ethics-wg-exp. Accessed 10 Oct 2015.

7. Nyika A, Kilama W, Chilengi R, Tangwa G, Tindana P, Ndebele P, Ikingura J. Composition, training needs and independence of ethics review committees across Africa: are the gate-keepers rising to the merging challenges? J Med Ethics. 2009:35:189-93. doi:10.1136/jme.2008.025189.

8. Wright GEB, Koornhof PGB, Adeyemo AA, Tiffin N. Ethical and legal implications of whole genome and whole exome sequencing in African populations. BMC Med Ethics. 2013;14:21. http://old.biomedcentral.com/ $1472-6939 / 14 / 21 /$.

9. UNESCO. International declaration on human genetic data. 2003. http://portal.unesco.org/en/ev.php-URL_ID=17720\&URL_DO=DO_ PRINTPAGE\&URL_SECTION=201.html.

10. Barchi F, Mathagela K, Jones N, Kebaabetswe PM, Merz JF. "The keeping is the problem": a qualitative study of IRB-member perspectives in Botswana on the collection, use, and storage of human biological samples for research. BMC Med Ethics. 2015;16:54. doi:10.1186/s12910-015-0047-3.

11. Staunton C, Moodley K. Challenges in biobank governance in Sub-Saharan Africa. BMC Med Ethics. 2013;14:35. http://www.biomedcentral.com/ 1472-6939/14/35

12. Dove ES, Tasse A-M, Knoppers BM. What are some of the ELSI challenges of international collaborations involving biobanks, global sample collection, and genomic data sharing and how should they be addressed? Biopreserve Biobank. 2014;12(6):363-4. doi:10.1089/bio.2014.1263.

13. Akintola SA. Ethical and legal issues in biobanking for genomic research in Nigeria. BEOnline. 2013;1(1):16-25.

14. Andana PA. Human tissue-related inventions: ownership and intellectual property rights in international collaborative research in developing countries. J Med Ethics. 2008;34(3):171-9. doi:10.1136/jme.2006.019612. 
15. Muula AS, Mfutso-Bengo JM. Responsibilities and obligations of using human research specimens transported across national boundaries. J Med Ethics. 2007;33:35-8.

16. Sathar MA, Dhai A. Laws, regulations and guidelines of developed countries, developing countries in Africa, and BRICS regions pertaining to the use of human biological material (HBM) in research. S Afr J BL. 2012;5:51-4.

17. Sathar MA, Dhai A, van de Linde S. Collaborative international research: ethical and regulatory issues pertaining to human biological materials at a South African institutional research ethics review committee. Dev World Bioethics. 2014;14(3):150-7.

18. World Health Organization. International Clinical Trials Registry Platform. http://apps.who.int/trialsearch/Default.aspx. Accessed 10 Oct 2015.

19. World Medical Association. Declaration of Helsinki - Ethical Principles for Medical Research Involving Human Subjects [64th WMA General Assembly, October 2013]. http://www.wma.net/en/30publications/10policies/b3/. Accessed 10 Oct 2015

20. Council for International Organizations of Medical Sciences (CIOMS). International Ethical Guidelines for Biomedical Research Involving Human Subjects 2002. http://www.recerca.uab.es/ceeah/docs/CIOMS.pdf.

21. The International Conference on Harmonization of Technical Requirements (ICH). E6 Good Clinical Practice: Consolidated Guidance. 1996. http://www. fda.gov/downloads/Drugs/Guidances/ucm073122.pdf.

22. Medical Research Council (MRC) -The Gambia. Guidelines of the National DNA Bank, The Gambia. Fajara, The Gambia: Medical Research Council, 2001.

23. UNESCO: Meeting to discuss the establishment of the National Bioethics Committee, N'Djamena, Chad, 29 July - 2 August, 2008. [SHS/EST/ABC/REP/10]. unesdoc.unesco.org/images/0016/001627/162750E.pdf.

24. UNESCO: 1st Preparatory Meeting on the Establishment of a National Ethics Committee in Gabon [SHS/EST/ABC/REP/09/Rev1]. 2007. http://unesdoc. unesco.org/images/0015/001559/155952e.pdf.

25. Malawi, National Health Sciences Research Committee. Policy Requirements Procedures and Guidelines for the Conduct and Review of Human Genetic Research in Malawi. 2012. Section 3.4.1 http://www.medcol.mw/comrec/wpcontent/uploads/2014/07/Human_Genetic Research_Procedures_and Guidelines.pdf.

26. Tanzania National Health Research Forum. Guidelines of Ethics for Health Research in Tanzania, 2nd Ed. [published by National Health Research Ethics Committee]. 2009; Section 8.8 http://clinregs.niaid.nih.gov/documents/ tanzania/G-EthicsHR.pdf.

27. Republic of Uganda, Uganda National Council for Science and Technology. National Guidelines for Research involving Humans as Research Participants. July 2014. https://www.swarthmore.edu/sites/default/files/assets/ documents/institutional-review-board/Human_Subjects_Protection_ Guidelines_July_2014.pdf.

28. UNESCO: Meeting with the Malgasch National Commission for the Ethics of Science and Technology (CMEST), Antananarivo, Madagascar, 20-25 June, 2007. http://unesdoc.unesco.org/images/0015/001528/152831E.pdf.

29. République du Benin. Loi No. 2005-31 du 05 Avril 2006: Portant prevention, prise en charge et contrôle du VIH SIDA en République du Benin. 2006. http://www.lo.org/wcmsp5/groups/public/_ed_protect/_protrav/_ilo_ aids/documents/legaldocument/wcms_125247.pdf.

30. République du Benin. Loi No. 2010-40 du 08 Decembre 2010: Portant code d'éthique et de déontologie pour la recherché en santé en République du Benin. 2010. http://www.ethique-sante.org/pdf/loi-portant-code-ethique.pdf.

31. Republic of Botswana. The Anthropological Research Act. 1967. http://www. elaws.gov.bw/docs/statutes/Botswana\%20Statute\%20Law\%201967.pdf.

32. Republic of Botswana. Drugs and related substances [Act No. 18 of 1992]. Gaborone: Government Printer; 1992.

33. Republic of Botswana, Drug Advisory Board. Guidelines on drug registration applications in Botswana. 4th ed. 2014. http://www.moh.gov.bw/Publications/ drug_regulation/Guidelines\%20on\%20Drug\%20Registration\%20Applications\%20 in\%20Botswana\%202014.pdf

34. Republic of Botswana, Ministry of Health. Standard operating procedures for review of biomedical and bio-behavioral research. 2011.

35. Burkina Faso: Loi No. 23/94/ADP of 19 May 1994 in the Code of Public Health, 1994.

36. Burkina Faso: Decret No. 2002-536/Portant creation d'un Comité d'éthique pour la recherché en santé au Burkina Faso, 2002.

37. Burkina Faso: Arrêté conjoint 2004/147/MS/MESSRS. Portant organization et functionnement du Comité d'éthique pour la recherche en santé au Burkina Faso (CERS), 2004
38. Republic of Cameroon, Ministry of Public Health. Arrêté No. 079/A/MSP/DS du Octobre 1987. Pourtant création et organization d'un comité d'éthique sur la recherché impliquant les êtres humains. 1987.

39. Republic of Cameroon, Ministry of Public Health. Décision No. 0674/D/MSP/ CIRCB du 13 Octobre 2006. 2006.

40. Democratic Republic of Congo, Ministry of Health. Politique nationale de recherché sur les systems de santé en République Democratique du Congo. 2004

41. Committee of Equatorial New Guinea (CENGE). 2014. http://guineaecuatorialpress. com/noticia.php?id=5849\&forcedfoto=1414523929.jpg\&lang=en. Accessed 10 Oct 2015.

42. Republic of Equatorial Guinea. Decree No. 125/2014 to constitute and name the inaugural members of the CENGE. 2014. http://guineaecuatorialpress. com/noticia.php?id=5849\&forcedfoto=1414523929.jpg\&lang=en.

43. Ethiopia (FDRE), Ministry of Science and Technology. National Research Ethics Guideline. 5th ed. 2014

44. The Gambia, Department of State for Health \& Social Welfare. National Health Research Policy: Research to protect and improve health, 2010-2014 [Revised draft for discussion 29/12/09].

45. The Gambia, Department of State for Health \& Social Welfare. National health Research Strategic Plan: Research to protect and improve health, 2010-2014 [Final draft: 15 January 2010]

46. Food and Drugs Authority (FDA). Guidelines for good clinical practice in Ghana. FDA/SMC/CTD/GL-GCP/2013/2. 27 January 2016.

47. Republic of Guinea: Decree No. D/218/PRG/SGG. On the Establishment, Functions and Organization of the National Ethics Committee for Research in Health (CNERS). 1998. http://cners-guinee.org/wp-content/uploads/2014/ 02/Decret-.pdf.

48. Republic of Kenya. Acts 2013: Special Issue. Republic of Kenya: Kenya Gazette Supplement No. 43 (Acts. No. 28) 25 Jan 2013.

49. Kenya, National Council for Science and Technology. Guidelines for ethical conduct of biomedical research involving human subjects in Kenya (NCST No. 45). 2004. https://www.nacosti.go.ke/newsletter/doc download/69-guidelines-for-ethical-conduct-of-research-involving-humansubjects-in-kenya.

50. Kenya Medical Research Institute (KEMRI). National Ethics Review Committee Guidelines and Standard Operating Procedures (SOPs). 2004. https://www. daidscrss.com/partners/Page_Regulatory_Management/Docs_Regulatory_ Management/Docs_Flag_Forms/Kenya_KEMRI_GUIDELINES_FINAL_ VERSION.pdf.

51. Republic of Kenya, Ministry of Health. Kenya National Guidelines for Research and Development of HIV/AIDS Vaccines. Republic of Kenya: Ministry of Health March; 2005.

52. Republic of Kenya, Pharmacy and Poisons Board. Guidelines for applications to conduct clinical trials in Kenya. 2011. www.pharmacyboardkenya.org/ downloads/?file=clinical_trial_guidelines.pdf.

53. Kingdom of Lesotho. National Health and Social Welfare Research Policy (NHSWRP), Lesotho. 2007. http://www.mindbank.info/item/1645.

54. Liberia Institute of Biomedical Research. Liberia Institute of Biomedical Research/National Health Science Research Ethics Committee Guidelines: procedures for researchers. 2011

55. University of Liberia-Pacific Institute for Research and Evaluation. Institutional Review Board (IRB) policies and procedures handbook. 2008. http://www.ulacre.org/wp-content/uploads/2013/03/UL-IRB-Policy-Handbook.pdf.

56. Republic of Liberia, Liberia Medicines and Health Products Regulatory Authority. Guideline for application to conduct clinical trials in Liberia. 1st ed. 2014. http://clinregs.niaid.nih.gov/documents/liberia/G-LibClinTrial.pdf.

57. Committee MNHSR. General guidelines on health research. 2007. http://www.aidsmalawi.org.mw/index.php/downloads/category/5-research.

58. Malawi: National Commission for Science and Technology. National policy measures and requirements for the improvement of health research co-ordination in Malawi [Sections 18 \& 48 of the Science and Technology Act of 2003]. Malawi: NCST; 2012. Revised.

59. Republic of Mali. Creation of a National Ethics Committee for Health and Life Sciences, No. 02-496/P-RM. 2002. http://elearning.trree.org/mod/folder/ view.php?id=164.

60. Republic of Mali. Minister of Health - Internal ruling: operation and functions of Committee for Health and Life Sciences. 2004. http://elearning. trree.org/mod/folder/view.php?id=164.

61. Republic of Mali. Fundamental principles of scientific and technological research, Loi 86-11 N RM. 1986. http://elearning.trree.org/mod/folder/view. php?id=164. 
62. Republic of Mali. Organization and functions of the National Institute of Public Health Research, 06-301 P-RM. 2006. http://elearning.trree.org/mod/ folder/view.php?id=164.

63. Republic of Mauritius. The clinical trials bill (No. XIX of 2010). 2010

64. Republic of Mozambique, Ministry of Health. Order of Minister of Health establishing the Comité national de bioética para saude. 2002.

65. World Health Organization (WHO). African Health Observatory (AFRO): Namibia- Research. http://www.aho.afro.who.int/profiles_information/index. php/Namibia:Research_-_Health_information,_research,_evidence_and_ knowledge. Accessed 10 Oct 2015.

66. Nigeria, Federal Ministry of Health, National Health Research Ethics Committee of Nigeria (NHREC). National code of health research ethics. 2006. http://www.nhrec.net/nhrec/National_Code_for_Health_Research_ Ethics_v2.0.pdf.

67. Nigeria, Federal National Health Research Ethics Committee of Nigeria. Policy statement on storage of human samples in biobanks and biorepositories in Nigeria (PS1.02013). 2013. http://nhrec.net/nhrec/NHREC_ Policy_Statement_on_Biobanks_FINAL.pdf.

68. Republic of Rwanda, Ministry of Health, National Ethics Committee. Standard operating procedures. 2009. http://www.rnecrwanda.org/images/ pdfs/standard_Operating_procedures_SOPs.pdf.

69. Republic of Rwanda, Ministry of Health. Guidelines for researchers intending to do health research in Rwanda. 2012. http://www.moh.gov.rw/fileadmin/ templates/PHIS/Researchers-Guidelines.pdf.

70. Republic of Senegal. Arrêté ministerial No. 3224 MSP-DERF-DER [March 17, 2004]. http://www.jo.gouv.sn/pip.php?article5037.

71. Republic of Senegal. Loi No. 2009-17, Code of Ethics for Health Research [March 9, 2009]. http://elearning.trree.org/mod/folder/view.php?id=179.

72. Republic of Senegal. Règlement Intérieur du Conseil National de la Recherche en Santé (Standard Operating Procedures) [March 7, 2006].

73. Republic of Sierra Leone, Ministry of Health and Sanitation, Pharmacy Board of Sierra Leone. Guidelines for conducting clinical trials of medicines, food supplements, vaccines, and medical devices in Sierra Leone (Version 02) (G-SLClinTrial). 2014

74. Republic of Sierra Leone, Ministry of Health and Sanitation, Pharmacy Board of Sierra Leone. Guideline for Good Clinical Practice (GCP) in Sierra Leone (Version 01) (SL-GCPS). 2014. http://clinregs.niaid.nih.gov/documents/ sierra_leone/G-SLClinTrial-PBSL.pdf.

75. Republic of Sierra Leone, Ministry of Health \& Sanitation, Office of the Sierra Leone Ethics and Scientific Review Committee. Sierra Leone Ethics and Scientific Review Committee -Guidelines. n.d.

76. Republic of South Africa. Act 61 of 2003 National Health Act, September 2003. [Current version in force]. http://www.lawsofsouthafrica.up.ac.za/index. php/current-legislation.

77. Republic of South Africa. Regulations relating to the use of human biological material [Government Notice R177 in Government Gazette 35099]. March 2, 2012. http://www.lawsofsouthafrica.up.ac.za/index.php/ browse/medical-and-health/national-health-act-61-of-2003/regulationsand-notices/61-of-2003-national-health-act-regs-gnr-183-2-mar-2012-todate-pdf/detail.

78. Republic of the Sudan, National Ministry of Health. National guidelines for ethical conduct of research involving human subjects. 2008. https:/healthresearchweb.org/en/sudan/policies.

79. United Republic of Tanzania. National Institute for Medical Research Act, No. 23 of 801979. 1979. http://elearning.trree.org/mod/folder/view. php?id=174.

80. United Republic of Tanzania. The Human DNA Regulation Act. 2009 http://www.tanzania.go.tz/egov_uploads/documents/The_Human_DNA_ Regulation_Act, 2009 (Act_No sw.pdf.

81. United Republic of Tanzania, National Institute of Medical Research. Standard Operating Procedures for the National Health Research Ethics Review Committee. 2007. http://www.nimr.or.tz/wp-content/uploads/2013/ 05/SOPs-_NIMR.pdf.

82. Republic of Uganda, Ministry of Health. National health policy. 1999. https://healthresearchweb.org/en/uganda/policies.

83. Government of Zambia. National Health Research Act, No. 2 of 2013. 2013. http://www.zambialaws.com/Principal-Legislation/NATIONAL-HEALTHRESEARCH-ACT.html.

84. Republic of Zimbabwe. Research Act, Chap 10:22. 1986. http://www.rcz.ac. zw/index.php/en/downloads.html.
85. Republic of Zimbabwe, Medical Research Council of Zimbabwe. Ethics Guidelines for Health Research involving Human Participants in Zimbabwe, Version 1.4. [September 30, 2011] https://www.daidscrss.com/partners/ Page_Regulatory_Management/Docs_Regulatory_Management/Docs_Flag_ Forms/Zimbabwe_conducting_health_research_in_zim.pdf .

86. Republic of Zimbabwe, Medicines Control Authority of Zimbabwe. Guidelines for good clinical trial practice in Zimbabwe. 2012. http://www. mcaz.co.zw/index.php/downloads/category/11-guidelines.

\section{Submit your next manuscript to BioMed Central and we will help you at every step:}

- We accept pre-submission inquiries

- Our selector tool helps you to find the most relevant journal

- We provide round the clock customer support

- Convenient online submission

- Thorough peer review

- Inclusion in PubMed and all major indexing services

- Maximum visibility for your research

Submit your manuscript at www.biomedcentral.com/submit
Biomed Central 